Original article

\title{
The influence of non-opiate analogue of leu-enkephalin to the cardiac consequences of intrauterine hypoxia of albino rats
}

\author{
Elena N. Sazonova ${ }^{1}$, Natalia A. Tcimbalist ${ }^{1}$, Olga V. Kaplieva ${ }^{1}$, Olga A. Lebed'ko ${ }^{2}$ \\ ${ }^{1}$ Far-Eastern State Medical University, Khabarovsk, Russia \\ ${ }^{2}$ Research Institute of Maternity and Childhood Protection, Khabarovsk, Russia
}

Received 26 June 2019, Revised 3 August 2019, Accepted 5 November 2019

(C) 2019, Sazonova E.N., Tcimbalist N.A., Kaplieva O.V., Lebed'ko O.A.

(C) 2019, Russian Open Medical Journal

Abstract: Objective - Our study aimed to evaluate the possibility of correcting cardiac consequences of intrauterine hypoxia (IUH) by injecting leu-enkephalin analog, lacking affinity for opiate receptors, in the early postnatal period.

Material and Methods - To model IUH, we placed pregnant Wistar rats in a hypobaric chamber with an oxygen partial pressure of 52 $\mathrm{mmHg}$. The procedure was repeated for $4 \mathrm{~h}$ daily over the $15^{\text {th }}-19^{\text {th }}$ days of gestation.

From the $2^{\text {nd }}$ through the $6^{\text {th }}$ days of their lives, the offspring were injected intraperitoneally with non-opiate leu-enkephalin analog at a dose of $100 \mu \mathrm{g} / \mathrm{kg}$ (NALE: Phe-D-Ala-Gly-Phe-Leu-Arg). This analog did not have affinity for opiate receptors. The 7- and 60-day old offspring of female rats subjected to IUH were investigated. The control group included the descendants of intact animals. We investigated gravimetric indicators, DNA-synthetic activity of cardiomyocytes (CMC) by tritium-labeled thymidine autoradiography method, the size of the CMC nuclei, as well as size and amount of nucleoli in the CMC nuclei. The activity of free radical oxidation was evaluated in cardiac homogenates by chemiluminescence.

Results - In 7-day old rats subjected to IUH vs. control animals, we observed decreases in body mass by $32.6 \%$, in heart mass by $27.3 \%$; in the proportion of ${ }^{3} \mathrm{H}$-thymidine labeled $\mathrm{CMC}$ nuclei by $32.7 \%$ in the left ventricle and by $30.4 \%$ in the right ventricle; in the number of nucleoli in the CMC nuclei (in the left ventricle: control $-2.384 \pm 0.027$, IUH $-2.282 \pm 0.027^{*}, \mathrm{p}<0.05$; in the right ventricle: control $2.409 \pm 0.038 ; \mathrm{IUH}-2.240 \pm 0.012 *, p<0,05)$. Increase in $\mathrm{CML}$ indices of cardiac homogenates was revealed, indicating the activation of free radical oxidation. In 7-day old rats subjected to IUH and administration of the NALE peptide from the $2^{\text {nd }}$ through the $6^{\text {th }}$ days of their lives, the proportion of ${ }^{3} \mathrm{H}$-thymidine labeled nuclei in the $\mathrm{CMC}$ did not differ from the control (in the left ventricle: control $-12.79 \pm 0.89 \%$, IUH + NALE $-10.98 \pm 0.95 \%, p>0.05$; in the right ventricle: control $-11.61 \pm 0.78 \%$; IUH + NALE $-11.26 \pm 0.58 \%, p>0.05)$. The number of nucleoli in the CMC nuclei of the left and right ventricles in the heart of 7-day old animals in the IUH + NALE group did not differ from the control too. The CML indices of heart homogenates in the IUH + NALE group were significantly lower than those in the IUH group.

In 60-day old male rats exposed to IUH, there was a decrease in heart mass by $18.5 \%$, sizes of CMC nuclei by $7.5 \%$ and $16.1 \%$ in the left and right ventricles, respectively, and in the total nucleoli area in the CMC nuclei of the left ventricle (control - 3.953 \pm 0.085 ; IUH $\left.3.372 \pm 0.078^{*} ; p<0.05\right)$. In 60-day old male rats subjected to IUH and injections of the NALE peptide from the $2^{\text {nd }}$ to the $6^{\text {th }}$ days of their lives, heart mass (control $-692.73 \pm 26.81 \mathrm{mg}$; IUH + NALE $-631.0 \pm 29.79 \mathrm{mg} ; \mathrm{p}>0.05$ ) and the size of the CMC nuclei of the right ventricle (control - 54.25 \pm 0.84 ; IUH + NALE - 55.24 $\pm 0.94 ; p>0.05$ ) did not differ significantly from the control. The size of the nuclei, the number and size of the nucleoli in the CMC of the left ventricle, as well as the area of the nucleoli in the CMC of the right ventricle in 60-day old male rats of the IUH + NALE group significantly exceeded control group values.

Conclusion - Administration of the NALE peptide to albino rats subjected to IUH normalized DNA-synthetic activity and the number of nucleoli in the nuclei of CMC in 7-day old animals, and also reduced the severity of oxidative stress in the heart tissue. In 60-day old albino male rats exposed to IUH, injecting NALE from the $2^{\text {nd }}$ to the $6^{\text {th }}$ days of their lives eliminated declines in heart mass and sizes of the CMC nuclei and nucleoli, and also led to an increase in the values of the nucleus-and-nucleolus complex indices compared with the control.

Keywords: intrauterine hypoxia, cardiomyocytes, biologically active peptides.

Cite as Sazonova EN, Cimbalist NA, Kaplieva OV, Lebed'ko OA. The influence of non-opiate analogue of leu-enkephalin to the cardiac consequences of intrauterine hypoxia of albino rats. Russian Open Medical Journal 2019; 8: e0401.

Correspondence to Elena N. Sazonova. Address: 167, Blucher st. 14, Khabarovsk, 680020. Phone: +79242063463. E-mail: sazen@mail.ru.

\section{Introduction}

Intrauterine hypoxia (IUH) induces pronounced changes in the myocardium of mammals. Resulting decrease in the proliferative and anabolic activities of cardiomyocytes (CMC) was noted by J.L.
Morrison et al. (2007) [1]; M. Ream et al. (2008) [2]; K.J. Botting et al. (2012) [3]. Myocardial damage in IUH conditions has significant clinical consequences [4], which can occur in the long run rather than at early stages of postnatal ontogenesis alone. D. Barker 
(2003) described the phenomenon of the so-called "fetal programming" in individuals born with an IUH-caused low body mass (suggesting an early gestational age) in the form of arterial hypertension and coronary heart disease in adulthood [5]. Hence, there is a vital need to search for the factors that can restore myocardium condition after an unfavorable intrauterine period.

Opioid peptides are crucial among endogenous factors with a cardioprotective effect. Enkephalins, endogenous ligands of $\delta$ opioid receptors, are considered the triggers of ischemic preconditioning of the myocardium [6].

The objective of our study was to evaluate the possibility of correcting early and long-term cardiac consequences of IUH by injecting a peptide leu-enkephalin analog in the neonatal period of ontogenesis.

\section{Material and Methods}

\section{Study object}

The study was performed on albino Wistar rats. The animals were kept in vivarium conditions at a temperature of $22^{\circ} \mathrm{C}$ and $a d$ libitum access to a standard granular food for laboratory rodents and water.

\section{Tested compound}

We used intraperitoneal administration of the Phe-D-Ala-GlyPhe-Leu-Arg peptide (Almabion, LLC, Russian Federation). The amino acid sequence in this peptide was similar to the structure of leu-enkephalin synthetic analog Dalargin (Tyr--D-Ala-Gly-Phe-LeuArg), a non-selective agonist of $\mu / \delta$-opiate receptors. However, the peptide in our study lacked affinity for opiate receptors due to the absence of tyrosine at the N-terminal position [7]. Hence, we named the Phe-D-Ala-Gly-Phe-Leu-Arg peptide "non-opiate analog of leu-enkephalin", or NALE peptide.

\section{Study design and experimental groups}

In order to conduct the experiment, 3-4 month old female rats were placed with sexually mature male rats at a 4:1 ratio. Pregnancy was established by the presence of sperm in vaginal smears. Pregnant female rats were subjected to $4 \mathrm{~h}$ hypoxic exposure daily over the $15^{\text {th }}-19^{\text {th }}$ days of gestation. A hypobaric hypoxia model was used: the animals were placed in an experimental hypobaric chamber, where atmospheric pressure was reduced to $250 \mathrm{mmHg}$, which corresponded to a partial oxygen pressure of $52 \mathrm{mmHg}$. Decreases and increases in pressure were conducted gradually, over $1 \mathrm{~h}$, to exclude barotrauma, and the duration of stationary hypoxia was $2 \mathrm{~h}$. Examination of the offspring of hypoxic female rats was conducted on the $7^{\text {th }}$ and the $60^{\text {th }}$ days of their ages. The control group included the progenies of intact animals.

Three experimental groups were formed:

1) The control group including the offspring of intact (not exposed to hypoxia) female rats subjected to daily intraperitoneal injections of $0.1 \mathrm{ml}$ isotonic sodium chloride solution from the $2^{\text {nd }}$ through the $6^{\text {th }}$ days of their lives.

2) IUH treatment group encompassing the offspring of hypoxic female rats subjected to daily intraperitoneal injections of $0.1 \mathrm{ml}$ isotonic sodium chloride solution from the $2^{\text {nd }}$ through the $6^{\text {th }}$ days of their lives.
3) IUH + NALE treatment group comprising of the offspring of hypoxic female rats subjected to daily intraperitoneal injections of NALE peptide (Almabion, LLC, Russian Federation) at a dose of $100 \mu \mathrm{g} / \mathrm{kg}$ in $0.1 \mathrm{ml}$ of solvent (isotonic sodium chloride solution) from the $2^{\text {nd }}$ through the $6^{\text {th }}$ days of their lives.

The animals were removed from the experiment by rapid decapitation under anesthesia with chloroform vapor. Body mass, absolute heart mass and heart mass index (heart mass to body mass ratio expressed in percent) of each animal were measured.

\section{Conducting histological and morphometric study}

Rat hearts underwent standard histological processing with paraffin tissue section preparation. To identify nucleolar organizer regions, heart sections (after dewaxing) were stained with silver nitrate according to the AgNOR method [8]. Morphometry of the CMC nucleus-and-nucleolus complex was executed on a MEKOS-C computer image analyzer: the size (area) of the CMC nucleus, the number and total area of the nucleoli in the $\mathrm{CMC}$ nucleus were evaluated. The CMC of subendocardial zones of the left and right heart ventricles were subjected to morphometry. The choice of myocardial zones was justified by the smallest representation of non-muscle heart cells in them [9] and their highest sensitivity to hypoxic effects [10].

\section{Conducting autoradiographic study}

DNA-synthetic activity of CMC in seven day old animals was evaluated using tritium-labeled thymidine autoradiography. One hour before euthanasia, animals were injected intraperitoneally with ${ }^{3} \mathrm{H}$-thymidine at a dose of $1 \mu \mathrm{Ci}$ per $1 \mathrm{~g}$ of a body mass. After a standard histological procedure, heart sections were dewaxed, covered with ILFORD nuclear emulsion (UK) and exposed in a lightproof container for $21 \mathrm{~d}$. After exposure, autoradiographs were treated with an X-ray developer, fixed in a $33 \%$ sodium hyposulfite solution and stained with hematoxylin and eosin. The labeling index (LI, \%) was determined by viewing $1000 \mathrm{CMC}$ nuclei in the subendocardial layer of the myocardium of the left and right heart ventricles.

\section{Conducting chemiluminescence study}

To analyze the activity of free radical oxidation in the heart homogenates of 7-day old animals, the chemiluminescence (CML) method was used. CML was recorded on an LS 50B PerkinElmer Inc. luminescent spectrometer. The signal was standardized using the FinLab firmware. The following indices were determined: $S_{s p}-$ total intensity of emitted light over 1 min of spontaneous CML; $\mathrm{H} 1$ - maximum amplitude of a fast flash of $\mathrm{Fe}^{2}{ }^{+}$-induced luminescence; $\mathrm{S}_{\text {ind1 }}$ - total intensity of emitted light over $2 \mathrm{~min}$ of $\mathrm{Fe}^{2+}$-induced $\mathrm{CML} ; \mathrm{H} 2$ is the maximum amplitude of the $\mathrm{H}_{2} \mathrm{O}_{2}{ }^{-}$ induced luminol-dependent $\mathrm{CML} ; \mathrm{S}_{\text {ind2 }}$ is the total intensity of emitted light over 2 min of $\mathrm{H}_{2} \mathrm{O}_{2}$-induced luminol-dependent CML. $\mathrm{CML}$ intensity was expressed in relative units.

\section{Statistical analysis}

Statistical processing of experimental data was conducted using Statistica 6.0 software. After confirming the normality of the data distributions, the sample means and standard errors were determined $-\mathrm{M} \pm \mathrm{SEM}$. Comparison of the groups was performed using the $t$-test. Differences were considered significant at $\mathrm{p}<0.05$. 
Table 1. Indicators of 7-day old albino rats subjected to IUH and neonatal administration of the non-opiate leu-enkephalin analog

\begin{tabular}{lccc} 
& Control & IUH & IUH + NALE \\
\hline Body mass, g & $16.07 \pm 0.61$ & $\begin{array}{c}10.83 \pm 0.91, \\
\mathrm{p}<0.001\end{array}$ & $\begin{array}{c}12.10 \pm 0.82, \\
\mathrm{p}<0.001\end{array}$ \\
\hline Heart mass, mg & $116.12 \pm 5.58$ & $\begin{array}{c}84.38 \pm 8.07 \\
\mathrm{p}=0.010\end{array}$ & $\begin{array}{c}89.29 \pm 9.86 \\
\mathrm{p}=0.040\end{array}$ \\
& & $0.78 \pm 0.03$ & $0.73 \pm 0.05$ \\
& $\mathrm{p}=0.120$ & $\mathrm{p}=0.720$ \\
\hline Heart mass index, \% & $0.72 \pm 0.03$ & $8.61 \pm 0.34$ & $10.98 \pm 0.95$ \\
& & $\mathrm{p}<0.001$ & $\mathrm{p}=0.37$ \\
\hline $\mathrm{CMC}$ labeling index of & $12.79 \pm 0.89$ & $8.08 \pm 1.04$ & $11.26 \pm 0.58$ \\
the LV, \% & & $\mathrm{p}=0.010$ & $\mathrm{p}=0.832$ \\
\hline $\mathrm{CMC}$ labeling index of & $11.61 \pm 0.78$ & $2.282 \pm 0.027$ & $2.399 \pm 0.040$ \\
the RV, \% & & $\mathrm{p}=0.025$ & $\mathrm{p}=0.540$ \\
\hline Nucleoli number in & $2.384 \pm 0.027$ & $2.240 \pm 0.012$ & $2.363 \pm 0.034$ \\
CMC nuclei of the LV & & $\mathrm{p}<0.001$ & $\mathrm{p}=0.461$ \\
\hline Nucleoli number in & $2.409 \pm 0.038$ & & \\
CMC nuclei of the RV & & &
\end{tabular}

CMC, cardiomyocytes; LV, left ventricle; RV, right ventricle; IUH, intrauterine hypoxia; NALE, Phe-D-Ala-Gly-Phe-Leu-Arg peptide; P-level is presented for differences in relation to the control group.

Table 2. Chemiluminescence indices of heart homogenates in 7-day old albino rats subjected to IUH and neonatal administration of the nonopiate leu-enkephalin analog

\begin{tabular}{|c|c|c|c|}
\hline & Control & IUH & $I U H+N A L E$ \\
\hline \multirow[t]{2}{*}{$\mathrm{S}_{\mathrm{sp}}$} & $1.434 \pm 0.088$ & $3.171 \pm 0.177$ & $2.271 \pm 0.133$ \\
\hline & & $* p<0.001$ & ${ }^{*} p=0.020, \# p=0.001$ \\
\hline \multirow[t]{2}{*}{$S_{\text {ind } 1}$} & $3.802 \pm 0.173$ & $7.186 \pm 0.368$ & $5.205 \pm 0.314$ \\
\hline & & ${ }^{*} p<0.001$ & ${ }^{*} \mathrm{P}=0.002, \# \mathrm{p}=0.001$ \\
\hline \multirow[t]{2}{*}{$\mathrm{H} 1$} & $1.251 \pm 0.095$ & $3.908 \pm 0.198$ & $2.122 \pm 0.204$ \\
\hline & & $* p<0.001$ & ${ }^{*} p=0.002, \# p<0.001$ \\
\hline \multirow[t]{2}{*}{$\mathrm{S}_{\text {ind } 2}$} & $8.968 \pm 0.395$ & $18.077 \pm 0.712$ & $10.996 \pm 0.432$ \\
\hline & & $* p<0.001$ & ${ }^{*} \mathrm{P}=0.004, \# \mathrm{p}<0.001$ \\
\hline \multirow[t]{2}{*}{$\mathrm{H} 2$} & $4.774 \pm 0.285$ & $15.088 \pm 0.477$ & $6.181 \pm 0.415$ \\
\hline & & $* p<0.001$ & ${ }^{*} \mathrm{P}=0.001, \# p<0.001$ \\
\hline
\end{tabular}

IUH, intrauterine hypoxia; NALE, Phe-D-Ala-Gly-Phe-Leu-Arg peptide; * Plevel is presented for differences in relation to the control group; \# P-level is presented for differences in relation to the IUH group.

Table 3. Indicators of 60-day old albino male rats subjected to IUH and neonatal administration of the non-opiate leu-enkephalin analog

\begin{tabular}{|c|c|c|c|}
\hline & Control & IUH & $I U H+N A L E$ \\
\hline Body mass, g & $144.86 \pm 5.75$ & $\begin{array}{c}130.75 \pm 4.33 \\
p=0.151\end{array}$ & $\begin{array}{c}139.50 \pm 6.08 \\
p=0.542\end{array}$ \\
\hline Heart mass, mg & $692.73 \pm 26.81$ & $\begin{array}{c}564.50 \pm 17.49 \\
p<0.001\end{array}$ & $\begin{array}{c}631.0 \pm 29.79 \\
p=0.112\end{array}$ \\
\hline Heart mass index, \% & $0.48 \pm 0.02$ & $\begin{array}{c}0.44 \pm 0.01 \\
p=0.091\end{array}$ & $\begin{array}{c}0.46 \pm 0.02 \\
p=0.453\end{array}$ \\
\hline $\begin{array}{l}\text { Nucleoli number in CMC } \\
\text { nuclei of the LV }\end{array}$ & $2.542 \pm 0.064$ & $\begin{array}{c}2.660 \pm 0.073 \\
p=0.180\end{array}$ & $\begin{array}{c}2.860 \pm 0.068 \\
p=0.007\end{array}$ \\
\hline $\begin{array}{l}\text { Nucleoli number in } \mathrm{CMC} \\
\text { nuclei of the RV }\end{array}$ & $2.448 \pm 0.058$ & $\begin{array}{c}2.570 \pm 0.068 \\
p=0.271\end{array}$ & $\begin{array}{c}2.495 \pm 0.066 \\
p=0.560\end{array}$ \\
\hline $\begin{array}{l}\text { Total area of the nucleoli } \\
\text { in the CMC of the LV }\end{array}$ & $3.953 \pm 0.085$ & $\begin{array}{c}3.372 \pm 0.078 \\
p<0.001\end{array}$ & $\begin{array}{c}4.725 \pm 0.115 \\
p<0.001\end{array}$ \\
\hline $\begin{array}{l}\text { Total area of the nucleoli } \\
\text { in the CMC of the RV }\end{array}$ & $3.383 \pm 0.074$ & $\begin{array}{c}3.325 \pm 0.091 \\
p=0.432\end{array}$ & $\begin{array}{c}3.665 \pm 0.089 \\
p=0.016\end{array}$ \\
\hline $\begin{array}{l}\text { Area of the nuclei in the } \\
\text { CMC of the LV }\end{array}$ & $51.84 \pm 0.94$ & $\begin{array}{c}47.97 \pm 0.98 \\
p=0.005\end{array}$ & $\begin{array}{c}61.54 \pm 0.91 \\
p<0.001\end{array}$ \\
\hline $\begin{array}{l}\text { Area of the nuclei in the } \\
\text { CMC of the RV }\end{array}$ & $54.25 \pm 0.84$ & $\begin{array}{c}45.52 \pm 0.92 \\
p<0.001\end{array}$ & $\begin{array}{c}55.24 \pm 0.94 \\
p=0.741\end{array}$ \\
\hline
\end{tabular}

CMC, cardiomyocytes; LV, left ventricle; RV, right ventricle; IUH, intrauterine hypoxia; NALE, Phe-D-Ala-Gly-Phe-Leu-Arg peptide; P-level is presented for differences in relation to the control group.

\section{Results}

Seven-day old animals exposed to IUH were characterized by a significant (32.6\%) reduction in body weights. A decrease in heart mass index (by $27.3 \%$ ) was also noted. Moreover, the heart mass index of 7-day old rats in a treatment group did not differ from the control (Table 1).

IUH caused a drop in the DNA-synthetic activity of myocardial cells in 7-day old animals: $\mathrm{LI}$ in the CMC of the left ventricle was reduced by $32.7 \%$ and of the right ventricle by $30.4 \%$ (Table 1 ). We also recorded a decrease in the nucleoli number of the $\mathrm{CMC}$ nuclei: by $4.3 \%$ in the left ventricle and by $7.0 \%$ in the right ventricle (Table 1).

In 7-day old animals subjected to IUH and five-time administration of the NALE peptide from the $2^{\text {nd }}$ through the $6^{\text {th }}$ days of their lives, a significant decrease in body weight (by 24.7\%) and heart weight (by 23.1\%) was registered, compared with the control group (Table 1). At the same time, injecting NALE peptide from the $2^{\text {nd }}$ through the $6^{\text {th }}$ days of life leveled out posthypoxic changes in DNA-synthetic processes and the nucleoli number in the CMC of experimental animals (Table 1). LI and nucleoli number in the $\mathrm{CMC}$ of the subendocardial layer of the left and right ventricles in 7-day old animals of the IUH + NALE group did not differ from the control values.

In the heart homogenates of 7-day old rats subjected to IUH, we recorded increases in the intensity of generation of reactive oxygen species (ROS) $\left(\mathrm{S}_{\mathrm{sp}}\right)$ by $121.1 \%$, in the content of peroxide radicals ( $\mathrm{H} 1$ ) in the tissue by $212.4 \%$, and in the rate of formation of peroxide radicals $\left(\mathrm{S}_{\text {ind1 }}\right)$ by $89.0 \%$ (Table 2 ). We also discovered a decline in peroxide resistance of the substrate (increase in $\mathrm{H} 2$ ) by $216 \%$ and the activity of the antioxidant defense system (increase in $S_{\text {ind } 2}$ ) by $101.6 \%$. In the heart homogenates of 7-day old rats subjected to IUH and five-time administration of the NALE peptide from the $2^{\text {nd }}$ to the $6^{\text {th }}$ days of their lives, a significant increase in $\mathrm{CML}$ indices was also revealed with respect to the control. However, the difference from the control values was significantly less pronounced than in the group of animals that did not receive peptide correction. Percent changes from the $\mathrm{S}_{\mathrm{sp}}$ indicator, $\mathrm{H} 1, \mathrm{~S}_{\text {ind1 }}$ $\mathrm{H} 2$ and $\mathrm{S}_{\text {ind2 }}$ were 58.4, 69.6, 36.9, 29.4 and 22.6, correspondingly. CML indices for the IUH + NALE group were significantly lower than for IUH group (Table 2).

In 60-day old male rats exposed to IUH, a decrease in the absolute heart mass by $18.5 \%$ was observed, compared with the parameter value in control group. An analysis of the morphometric parameter values of the CMC nucleus-and-nucleolus complex revealed a decrease in the size of the $\mathrm{CMC}$ nuclei of subendocardial parts of the left and right ventricles (by $7.5 \%$ and $16.1 \%$, respectively), and in the average total area of the nucleoli in the CMC nuclei of the subendocardial layer of the left ventricle by $14.7 \%$ (Table 3).

60-day old male rats subjected to IUH and five-time administration of the NALE peptide from the $2^{\text {nd }}$ through the $6^{\text {th }}$ days of their lives had a body mass that did not differ from the control group value (Table 3 ). In the animals of this group, in contrast to the IUH group, we did not register any decrease in morphometric parameters of the CMC nucleus-and-nucleolus complex. Moreover, in male rats of the IUH + NALE group, compared with control animals, we detected an increase in the size of the nuclei by $18.7 \%$, along with increases in the number of nucleoli by $12.5 \%$ in the $\mathrm{CMC}$ of the left ventricle and in the total 
area of the nucleoli in the nuclei of the left and right ventricles' CMC by $19.5 \%$ and $8.3 \%$, respectively.

\section{Discussion}

IUH induces a decrease in the DNA-synthetic activity of CMC in the developing heart. We have previously shown that albino rats exposed to IUH had a reduction in the DNA-synthetic activity of CMC at the age of 1-day old [11]. In the current study, a similar effect was shown for 7-day old animals. L.M. Reyes et al. (2018) reported a decrease in the proliferative activity of heart cells in mammals after prenatal hypoxia [12]. CMC proliferation occurs in mammals, mainly in the antenatal and early postnatal periods of ontogenesis [13]. S. Bae et al. (2003) stated a significant decrease in the $\mathrm{CMC}$ numbers and their hypertrophic changes in the heart of newborn rats that have undergone IUH [14]. The number of $\mathrm{CMC}$ and their ploidy determine the structural reserve of the heart over the subsequent ontogenetic periods [13].

In addition to impaired DNA synthesis in experimental newborn animals exposed to IUH, we detected a decline of the nucleoli number in the CMC nuclei at the ages of 1-day old [11] and 7-day old. A decrease in the nucleoli number and disruption in the structure of the $\mathrm{CMC}$ nucleolar complex reflects the condition of the cellular stress, and correlates with the induction of apoptosis and with increased content of p53 protein, which has both antiproliferative and proapoptotic effects on cells [15].

CMC structural changes were accompanied by significant oxidative stress at a tissue level. In heart tissue homogenates of experimental 7day old animals, we recorded stimulation of free radical oxidation and decrease in antioxidant activity. Hypoxia is a classic inducer of oxidative stress in cells. Under IUH, oxidative stress is exacerbated by the low activity of antioxidant systems in fetal cells and cells of newborn mammals. An excess of reactive oxygen species (ROS) during oxidative stress causes epigenetic changes. It is shown that IUH, through an increase in the concentration of ROS in tissues, induces a decrease in the amount of protein kinase $C \varepsilon$ in the hearts of rat fetuses, which is associated with DNA hypermethylation in the promoter of the $C \varepsilon$ protein kinase gene [16]. Protein kinase $C \varepsilon$ plays a significant role in the processes of CMC growth and adaptation of heart cells to damaging factors [17].

Deviations in the values of the indices reflecting the state of the heart in the animals subjected to IUH were maintained at least until the period of maturity. In 60-day old male rats subjected to IUH, we found a decrease in heart mass, a decrease in the size of the $\mathrm{CMC}$ nuclei, as well as a smaller total area of the nucleoli in the $\mathrm{CMC}$ nuclei of the left ventricle. In our previous study conducted on the same experimental model, we detected a decrease in the nucleoli number in the CMC nuclei [11]. The revealed changes may indicate the persistence of structural deficit in the myocardium of adult animals exposed to IUH, and a decrease in the functional reserves of the hearts in experimental animals [18]. This corresponds to the "fetal programming" concept [5], which describes the relationship between the fetal growth retardation syndrome, caused by unfavorable conditions for intrauterine ontogenesis, and the formation of cardiovascular pathology at later ontogenetic stages [19].

We assumed the possibility of correcting posthypoxic changes in the heart and eliminating unfavorable cardiac manifestations of fetal programming via using neonatal administration of the NALE peptide. The choice of the exposure period was justified by the fact that DNA methyltransferase activity, which determines epigenetic changes, is closely related to the DNA-synthetic activity of cells [20]. The latter reaches the maximum for $C M C$ in rats during the neonatal period. Administering opioid receptor ligands at early ontogenetic stages can cause hormonal imprinting of the endogenous opioid system and irreversible changes in its functioning [21]. This fact defined our interest in a biologically active peptide, lacking affinity for opioid receptors.

Administration of NALE peptide from the $2^{\text {nd }}$ through the $6^{\text {th }}$ days of life did not normalize gravimetric indices of experimental 7-day old animals. A decrease in gravimetric indices' values under the influence of IUH is formed in the antenatal period and is detected immediately after birth in 1-day old experimental rat pups [11]. In the current study, the introduction of the peptide in the neonatal period could not lead to the rapid restoration of body mass and heart mass of experimental animals. However, the effects of NALE have corrected the posthypoxic abnormalities of the DNA-synthetic activity of CMC and changes in the nucleolar complex of myocardial cells in 7-day old animals subjected to IUH. The corrective effect of the neonatal administration of the NALE peptide on the cardiac consequences of IUH may be due to its ability to normalize the processes of free radical oxidation at the tissue level under conditions of oxidative stress. CML-indicators of free radical oxidation in the heart homogenates of 7-day old rats subjected to IUH and neonatal administration of the NALE peptide had significantly lower values than those in animals undergoing IUH without peptide correction. The revealed effect implied the presence of pronounced antioxidant properties in the NALE peptide. Earlier, we discovered the antioxidant and cytoprotective effect of the NALE peptide in vitro [22], which indicated a direct action mechanism of the peptide without mediation by the regulatory systems of the body.

In 60-day old animals subjected to IUH, posthypoxic changes in the heart condition (decreased heart mass, decreased size of the nuclei and nucleoli in $\mathrm{CMC}$ ) were completely offset by the introduction of the NALE peptide during the neonatal period. Moreover, in animals treated with the peptide from the $2^{\text {nd }}$ through the $6^{\text {th }}$ days of life, we detected an increase in the CMC nucleus-and-nucleolus complex indices versus control values. The discovered changes could be accounted for by increased anabolic activity of CMC in adult animals treated with the NALE peptide over the neonatal period.

The mechanisms of the "reprogramming" effect of the NALE peptide on CMC require further investigation. Currently, the research is underway to assess the involvement of the nitric oxide system and the nociceptin peptide system in the implementation of NALE effects.

\section{Conclusion}

Non-opiate leu-enkephalin analog injections in the neonatal period of ontogenesis eliminated a number of early and delayed pathological changes in the heart of experimental animals subjected to IUH. Thus, this particular Phe-D-Ala-Gly-Phe-Leu-Arg peptide can be considered a promising basic tool for the development of a pharmaceutical drug intended for the correction of IUH cardiac consequences.

\section{Limitations}

Each experimental group included 12-14 animals. While greater sample sizes could have increased the reliability of our 
results, high complexity of experimental design and morphometric measurements have limited the numbers of animals involved in the study. Besides, we followed the ethical principles set forth in the "European Convention for the Protection of Vertebrate Animals Used for Experiments or for Other Scientific Purposes" (Strasbourg, 1986) on using the minimum sufficient animal numbers to obtain statistically significant results.

The resulting morphometric indices may have had inaccuracies associated with morphometry conducted on tissue sections rather than isolated cardiomyocytes.

\section{Ethical approval}

The study took into account all international, national and institutional requirements for animal welfare and experimental procedures. The experiments were carried out in accordance with the guidelines of the "European Convention for the Protection of Vertebrate Animals Used for Experiments or for Other Scientific Purposes" (Strasbourg, 1986). The study received permission from the Ethics Committee of the Federal State Budgetary Institution of Higher Education, The Far Eastern State Medical University of the Russian Federation Ministry of Healthcare, the protocol No. 2 of February 5, 2019). In total, 112 animals were included in our experiments.

\section{Funding}

The reported study was funded by RFBR according to the research project № 19-015-00020.

\section{Conflict of interest: none declared.}

\section{Acknowledgments}

The authors are grateful to Stepan I. Zubenko, Pavel Yu. Tsuprun, Aleksander O. Mikhaylichenko and Tatyana A. Kharchenko for their methodological assistance in conducting the study.

\section{References}

1. Morrison JL, Botting KJ, Dyer JL, Williams SJ, Thornburg KL, McMillen IC. Restriction of placental function alters heart development in the sheep fetus. Am J Physiol Regul Integr Comp Physiol 2007; 293(1): R306-R313. https://doi.org/10.1152/ajpregu.00798.2006.

2. Ream M, Ray AM, Chandra R, Chikaraishi DM. Early fetal hypoxia leads to growth restriction and myocardial thinning. Am J Physiol Regul Integr Comp Physiol 2008; 295(2): R583-R595. https://doi.org/10.1152/ajpregu.00771.2007.

3. Botting KJ, Wang KC, Padhee M, McMillen IC, Summers-Pearce B, Rattanatray $L$, et al. Early origins of heart disease: low birth weight and determinants of cardiomyocyte endowment. Clin Exp Pharmacol Physiol 2012; 39(9): 814-823. https://doi.org/10.1111/j.14401681.2011.05649.x.

4. Lebedenko AA, Tarakanova TD, Kozyreva TB, Levchin AM, Averkina LA Time course of cardiac structural and functional changes in babies in the first year of life who have sustained transient myocardial ischemia in the early neonatal period. Russian Bulletin of Perinatology and Pediatrics 2017; 62(1): 53-59. Russian. https://doi.org/10.21508/10274065-2017-62-1-53-59.

5. Barker D. The midwife, the coincidence and the hypothesis. BMJ 2003; 327(7429): 1428-1430. https://doi.org/10.1136/bmj.327.7429.1428.

6. Maslov LN, Naryzhnaya NV, Podoksenov YuK, Mrochek AG, Gorbunov AS, Tsibulnikov SYu. Opioids - triggers of adaptive phenomenon of ischemic preconditioning of heart. Russian Journal of Physiology 2014; 100(9): 993-1003. Russian. https://elibrary.ru/item.asp?id=22018785.

7. Lasukova TV, Maslov LN, Podoksenov YuK, Podoksenov AYu, Platonov AA, Ovchinnikov MV, et al. Effect of opiate peptide dalargin and des-
Tyr-dalargin on cardiac pump function during ischemia-reperfusion Bull Exp Biol Med 2004; 137(1): 27-30. Russian. https://doi.org/10.1023/b:bebm.0000024378.48252.fb.

8. Trerè D. AgNOR staining and quantification. Micron 2000; 31(2): 127 131. https://doi.org/10.1016/s0968-4328(99)00069-4.

9. Bazhenova EM, Lebedinsky GN, Borodina GN, Tyuryumina OV, Chernov AV. Morphology and biomechanics of the heart. Morphology 2000; 117(3): 17. Russian https://elibrary.ru/item.asp?id=25486874.

10. Sokolova NA, Maslova MV, Maklakova AS, Ashmarin IP. Prenatal hypoxic stress: physiological and biochemical consequences, correction by regulator peptides. Usp Fiziol Nauk 2002; 33(2): 56-67. Russian. https://www.ncbi.nlm.nih.gov/pubmed/12004578

11. Zubenko SI, Yan L, Zhul'kov MO, Lebed'ko OA, Sazonova EN. Effects of antenatal hypoxia on tissue homeostasis in the myocardium of albino rats: early and delayed consequences. Bull Exp Biol Med 2014; 157(3): 320-323. Russian. https://doi.org/10.1007/s10517-014-2555-4.

12. Reyes LM, Shah A, Quon A, Morton JS, Davidge ST. The role of the tumor necrosis factor (TNF)-related weak inducer of apoptosis (TWEAK) in offspring exposed to prenatal hypoxia. J Dev Orig Health Dis 2018; 9(6): 661-669. https://doi.org/10.1017/S2040174417001003.

13. Brodskiĭ Via. Polyploidy in the myocardium. Compensatory reserve of the heart. Bull Exp Biol Med 1995; 119(5): 454-459. Russian. https://www.ncbi.nlm.nih.gov/pubmed/7579231.

14. Bae S, Xiao Y, Li G, Casiano CA, Zhang L. Effect of maternal chronic hypoxic exposure during gestation on apoptosis in fetal rat heart. Am J Physiol Heart Circ Physiol 2003; 285(3): H983-H990. https://doi.org/10.1152/ajpheart.00005.2003.

15. Avitabile D, Bailey B, Cottage CT, Sundararaman B, Joyo A, McGregor $M$, et al. Nucleolar stress is an early response to myocardial damage involving nucleolar proteins nucleostemin and nucleophosmin. Proc Natl Acad Sci U S A 2011; 108(15): 6145-6150. https://doi.org/10.1073/pnas.1017935108

16. Patterson AJ, Xiao D, Xiong F, Dixon B, Zhang L. Hypoxia-derived oxidative stress mediates epigenetic repression of $\mathrm{PKC} \varepsilon$ gene in foetal rat hearts. Cardiovasc Res 2012; 93(2): 302-310. https://doi.org/10.1093/cvr/cvr322.

17. Song $M$, Matkovich SJ, Zhang $Y$, Hammer DJ, Dorn GW. Combined cardiomyocyte $\mathrm{PKC} \delta$ and $\mathrm{PKC} \varepsilon$ gene deletion uncovers their central role in restraining developmental and reactive heart growth. Sci Signal 2015; 8(373): ra39 https://doi.org/10.1126/scisignal.aaa1855.

18. Rueda-Clausen CF, Morton JS, Lopaschuk GD, Davidge ST. Long-term effects of intrauterine growth restriction on cardiac metabolism and susceptibility to ischaemia/reperfusion. Cardiovasc Res 2011; 90(2): 285-294. https://doi.org/10.1093/cvr/cvq363.

19. Nagaeva EV, Shiryaeva TYu. "Intrauterine programming" of hormonal and metabolic processes and intrauterine growth retardation syndrome. Problems of Endocrinology 2010; 56(6): 32-40. Russian. https://elibrary.ru/item.asp?id=16555347.

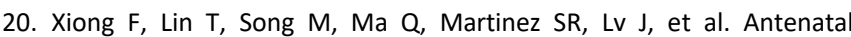
hypoxia induces epigenetic repression of glucocorticoid receptor and promotes ischemic-sensitive phenotype in the developing heart. $J \mathrm{Mol}$ Cell Cardiol 2016; 91: 160-171. https://doi.org/10.1016/j.yjmcc.2016.01.003.

21. Csaba G, Tekes K. Is the brain hormonally imprintable? Brain Dev 2005; 27(7): 465-471. https://doi.org/10.1016/j.braindev.2004.12.008.

22. Sazonova EN, Lebed'ko OA, Denisyuk GA, Zhmerenetskiy KV, Dobrykh VA. Cytoprotective effect of non-opioid leu-enkephalin analogue in primary culture of pulmonary fibroblasts in oxidative stress. Kazan medical journal 2019; 100(1): 153-157. Russian. https://doi.org/10.17816/KMJ2019-153.

\section{Authors:}

Elena N. Sazonova - MD, DSc, Associate Professor, Vice-Rector for Research, Head of the Department of Normal and Pathological Physiology, 
Far-Eastern State Medical University, Khabarovsk, Russia. http://orcid.org/0000-0002-8668-492X.

Natalia A. Cimbalist - PhD, Associate Professor, Senior Researcher, Central Research Laboratory, Far-Eastern State Medical University, Khabarovsk, Russia. http://orcid.org/0000-0003-0244-9576.

Olga V. Kaplieva - PhD, Associate Professor, Head of the Faculty of Pediatrics, Associate Professor of the Department of Hospital and Faculty Pediatrics with a course of Propaedeutics of Childhood Diseases, FarEastern State Medical University, Khabarovsk, Russia. http://orcid.org/0000-0002-3074-6706.

Olga A. Lebed'ko - MD, DSc, Director, Research Institute of Maternity and Childhood Protection, Khabarovsk, Russia. http://orcid.org/0000-00028855-7422. 